\title{
Quantifying the Severity of Acute Lung Injury Using Dead-Space Ventilation: Should the Lung Injury Score Be Updated?
}

During the past decade of research on acute lung injury (ALI) and acute respiratory distress syndrome (ARDS) there has been heightened interest in measuring physiologic dead-space fraction $\left(\mathrm{V}_{\mathrm{D}} / \mathrm{V}_{\mathrm{T}}\right)$. Since ARDS first was described 44 years ago, the primary focus on gas exchange abnormalities concerned oxygenation. In fact, until the publication in 2002 by Nuckton et al, ${ }^{1}$ pulmonary dead-space ventilation was considered relevant only in the subacute or fibroproliferative phase. ${ }^{2}$ This impression probably reflected preoccupation with the problem of improving oxygenation. In contrast, it was relatively easy to achieve normocapnia simply by raising minute ventilation. In retrospect, the advent of lung-protective ventilation and permissive hypercapnia focused more attention on the issue of impaired carbon dioxide excretion in patients with ALI/ARDS.

Interest in measuring $\mathrm{V}_{\mathrm{D}} / \mathrm{V}_{\mathrm{T}}$ grew rapidly following publication of the ARDS Network ARMA study ${ }^{3}$ and the aforementioned study by Nuckton et al. ${ }^{1}$ Lung-protective ventilation was the first therapy ever shown to reduce mortality in ARDS. Moreover, elevated $\mathrm{V}_{\mathrm{D}} / \mathrm{V}_{\mathrm{T}}$ can be a sign of lung over-distention. ${ }^{4}$ A markedly elevated $\mathrm{V}_{\mathrm{D}} / \mathrm{V}_{\mathrm{T}}$ can develop early in the course of ARDS, and it has a strong association with higher mortality. One issue involved how much of the elevated pulmonary dead space reflected an injurious mechanical ventilation strategy or more severe lung injury.

Since 2002, numerous studies have explored the prognostic, pathophysiologic, and therapeutic utility of measuring $\mathrm{V}_{\mathrm{D}} / \mathrm{V}_{\mathrm{T}}$ in ALI/ARDS. Its value in predicting mortality has been reaffirmed by several studies. ${ }^{5-8}$ The specific value of measuring $\mathrm{V}_{\mathrm{D}} / \mathrm{V}_{\mathrm{T}}$ to increase our understanding of the pathophysiology of ARDS is based upon carbon dioxide's relatively high diffusability across tissue membranes, compared to oxygen. ${ }^{9}$ Thus $\mathrm{V}_{\mathrm{D}} / \mathrm{V}_{\mathrm{T}}$ is a more perfusion-sensitive variable that may be useful as an indirect marker for pulmonary endothelial injury. In ALI/ARDS, endothelial injury is associated with coagulation disorders and fibroproliferation, both of which are associated with increased mortality. ${ }^{10}$ For example, a recent study found that elevated $\mathrm{V}_{\mathrm{D}} / \mathrm{V}_{\mathrm{T}}$, coupled with biomarkers of pulmonary endothelial injury, was a strong predictor for mortality in patients with ALI/ARDS. ${ }^{11}$

Other recent studies have used $\mathrm{V}_{\mathrm{D}} / \mathrm{V}_{\mathrm{T}}$ to assess the therapeutic impact of pharmacologic, positional, and ventila- tor interventions. In the current issue of the Journal, Raurich and colleagues ${ }^{12}$ report that $\mathrm{V}_{\mathrm{D}} / \mathrm{V}_{\mathrm{T}}$ was elevated markedly in the subacute phase of ARDS, and decreased significantly in response to treatment with methylprednisolone. These findings provide indirect evidence regarding the mechanism by which methylprednisolone improves pulmonary function in ARDS: namely, its ability to decrease both collagen formation and platelet adhesion that in part may be responsible for pulmonary microcirculatory obstruction. ${ }^{13}$ In addition, Raurich et al's findings of reduced $V_{D} / V_{T}$ are similar to those who reported the effects of activated protein $\mathrm{C}$ in patients with ALI/ARDS, ${ }^{14,15}$ as well as those studying the effects of heparin therapy on microvascular thrombosis in patients undergoing cardiac surgery. ${ }^{16}$

See the Original Study on Page 377

Measurement of $\mathrm{V}_{\mathrm{D}} / \mathrm{V}_{\mathrm{T}}$ also has been valuable in assessing the effects of lung recruitment, both in patients with severe ARDS ${ }^{17-20}$ and in animal models of ALI. ${ }^{21,22}$ Of particular interest is that measuring $\mathrm{V}_{\mathrm{D}} / \mathrm{V}_{\mathrm{T}}$ may be superior to oxygenation indices in assessing lung recruitment. ${ }^{19}$ Likewise, deterioration in $\mathrm{V}_{\mathrm{D}} / \mathrm{V}_{\mathrm{T}}$ is more sensitive than oxygenation indices in detecting lung de-recruitment during a PEEP decrement trial. ${ }^{21}$

Previously we had speculated that an elevated $\mathrm{V}_{\mathrm{D}} / \mathrm{V}_{\mathrm{T}}$ in ALI/ARDS in part represents pulmonary endothelial damage and reflects the severity of both pulmonary arterial and microvascular obstruction. ${ }^{1,5}$ However, others ${ }^{23,24}$ have correctly pointed out that the carbon dioxide-based dead-space measurement is sensitive to any ventilation-perfusion imbalance. Moreover, this ventilation-perfusion ratio imbalance appears skewed, particularly toward the mid-range, as opposed to the high-range and pure dead-space ventilation. Although this does not negate the likely contribution of vascular injury, it does emphasize that these lung abnormalities do not account for all of the increase in the $\mathrm{V}_{\mathrm{D}} / \mathrm{V}_{\mathrm{T}}$ in ALI/ARDS patients. One could reasonably conclude that $\mathrm{V}_{\mathrm{D}} / \mathrm{V}_{\mathrm{T}}$ is just more representative of overall lung damage and subsequent mortality risk, regardless of the relative distribution of physiologic and pathogenetic factors that contribute to it. On this issue, others appear to be in agreement also. ${ }^{22-24}$ 
Over 2 decades ago, Murray and colleagues 25 created the first quantitative measurement of lung injury severity. This score integrated abnormalities in respiratory-system compliance, oxygenation, and chest radiograph with the level of PEEP. Although the lung injury score has been valuable in quantifying the severity of lung dysfunction, it has not been particularly useful in predicting mortality. ${ }^{26}$ The cumulative evidence reviewed here is remarkably consistent in demonstrating the value of $\mathrm{V}_{\mathrm{D}} / \mathrm{V}_{\mathrm{T}}$ in both the study and management of ARDS. Therefore, we should perhaps consider updating the 4-point lung injury score to incorporate $\mathrm{V}_{\mathrm{D}} / \mathrm{V}_{\mathrm{T}}$, making it a 5-point scoring system. The expectation would be that this modification may provide a more complete assessment of injury severity and may improve its overall prognostic value. A reasonable scoring scheme for $\mathrm{V}_{\mathrm{D}} / \mathrm{V}_{\mathrm{T}}$ might be: $\leq 0.39(0), 0.40-$ 0.49 (1), 0.50-0.59 (2), 0.60-0.69 (3), $\geq 0.70$ (4).

Although variation in measurement technique presents some important technical considerations (most notably controlling for the effects of compression volume contamination), ${ }^{27}$ these are relatively minor. Regardless, both volumetric capnography and indirect calorimetry now are readily available in most intensive care units. Therefore, measuring $\mathrm{V}_{\mathrm{D}} / \mathrm{V}_{\mathrm{T}}$ is practical and could be incorporated in assessing patients with ALI/ARDS in both academic and community based intensive care units.

The past decade of research on dead-space ventilation has been impressive in the new insights it has generated about both the pathophysiology of ALI/ARDS and the utility of measuring $\mathrm{V}_{\mathrm{D}} / \mathrm{V}_{\mathrm{T}}$ for assessing new therapies. We eagerly look forward to the possibility that the next 10 years of research on dead-space ventilation will further enrich our understanding.

Richard H Kallet MSc RRT FAARC Respiratory Care Services Department of Anesthesia University of California, San Francisco San Francisco, California

James A Alonso RN RRT Department of Nursing San Francisco General Hospital University of California, San Francisco San Francisco, California

Michael A Matthay MD

Cardiovascular Research Institute Pulmonary and Critical Care Medicine University of California, San Francisco San Francisco, California

\section{REFERENCES}

1. Nuckton T, Alonso J, Kallet R, Daniel B, Pittet JP, Eisner M, Matthay MA. Early elevation in dead-space ventilation is associated with mortality risk in patients with acute respiratory distress syndrome. N Engl J Med 2002;346(17):1281-1286.

2. Luce JM. Acute lung injury and acute respiratory distress syndrome. Crit Care Med 1998;26(2):369-376.

3. The Acute Respiratory Distress Syndrome Network. Ventilation with lower tidal volumes as compared with traditional tidal volumes for acute lung injury and the acute respiratory distress syndrome. N Engl J Med 2000;342(18):1301-1308.

4. Suter PM, Fairley HB, Isenberg MD. Optimal end-expiratory airway pressure in patients with acute pulmonary failure. N Engl J Med 1975;292(6):284-289.

5. Kallet RH, Alonso JA, Pittet JF, Matthay MA. Prognostic value of the pulmonary dead-space fraction during the first 6 days of acute respiratory distress syndrome. Respir Care 2004;49(9):10081014.

6. Cepkova M, Kapur V, Ren X, Quinn T, Zhuo H, Foster E, Liu KD, Matthay MA. Pulmonary dead space fraction and pulmonary artery systolic pressure as early predictors of clinical outcome in acute lung injury. Chest 2007;132(3):836-842.

7. Lucangelo U, Bernable F, Vatua S, DEgrassi G, Villagra A, Fernandez R, Romero PV, Saura P, Borelli M, Blanch L. Prognostic value of different dead space indices in mechanically ventilated patients with acute lung injury and ARDS. Chest 2008;133(1):62-71.

8. Raurich JM, Vilar M, Colomar A, Ibanez J, Ayestaran I, PerezBarcena J, Llompart-Pou JA. Prognostic value of the pulmonary dead-space fraction during early and intermediate phases of acute respiratory distress syndrome. Respir Care 2010;55(3):282-287.

9. West JB. Respiratory physiology: the essentials, 8th edition. Philadelphia: Lippencott Williams \& Williams; 2008:26.

10. Ware LB, Matthay MA. The acute respiratory distress syndrome. N Engl J Med 2000;342(18):1334-1349.

11. Ong T, McClintock DE, Kallet RH, Ware LB, Matthay MA, Liu KD. Ratio of angiopoietin-2 to angiopoietin-1 as a predictor of mortality in acute lung injury patients. Crit Care Med 2010;38(9):1-7.

12. Raurich JM, Ferreruela M, Llompart-Pou JA, Vilar M, Colomar A, Ayestaran I, Perez-Barcena J, Ibanez J. Potential effects of corticosteroids on physiologic dead space fraction in acute respiratory distress syndrome. Respir Care 2012;57(3):377-383.

13. Meduri GU, Headley AS, Golden E, Carson SJ, Umberger RA, Kelso T, Tolley EA. Effect of prolonged methylprednisolone therapy in unresolving acute respiratory distress syndrome. JAMA 1998; 280(2):159-165.

14. Liu KD, Levitt J, Zhuo H, Kallet RH, Brady S, Steingrub J, Tidswell M, Siegel MD, Soto G, Peterson MW, Chesnutt MS, Phillips C, Weinacker A, Thompson BT, Eisner MD, Matthay MA. Randomized clinical trial of activated protein $\mathrm{C}$ for the treatment of acute lung injury. Am J Respir Crit Care Med 2008;178(6):618-623.

15. Kallet RH, Jasmer RM, Pittet JF. Alveolar dead-space response to activated protein $\mathrm{C}$ in acute respiratory distress syndrome. Respir Care 2010;55(5):617-622.

16. Dixon B, Campbell DJ, Santamaria JD. Elevated pulmonary dead space and coagulation abnormalities suggests microvascular thrombosis in patients undergoing cardiac surgery. Intensive Care Med 2008;34(7):1216-1223.

17. Gattinoni L, Vagginelli F, Carlesso E, Taccone P, Conte V, Chiumello D, Valenza F, Caironi P, Pesenti A. Decrease in $\mathrm{PaCO}_{2}$ with prone position is predictive of improved outcome in acute respiratory distress syndrome. Crit Care Med 2003;31(12):2727-2733.

18. Gattinoni L, Caironi P, Cressoni M, Chiumello D, Ranieri VM, Quintel M, Russo S, Patroniti N, Cornejo R, Bugedo G. Lung recruitment in patients with the acute respiratory distress syndrome. N Engl J Med 2006;354(17):1771-1786. 
19. Charron C, Repesse X, Bouferrache K, Bodson L, Castro S, Page B, Jardin F, Vieillard-Baron A. $\mathrm{P}_{\mathrm{aCO}_{2}}$ and alveolar dead space are more relevant than $\mathrm{P}_{\mathrm{aO}_{2}} / \mathrm{F}_{\mathrm{IO}}$ in monitoring the respiratory response to prone position in acute respiratory distress syndrome patients: a physiologic study. Critical Care 2011;15R:175.

20. Maisch S, Reissmann H, Fuellekrug B, Weismann D, Rutkowski T, Tusman G, Bohm SH. Compliance and dead space fraction indicate an optimal level of positive end-expiratory pressure after recruitment in anesthetized patients. Anesth Analg 2008;106(1):175-181.

21. Tusman G, Suarez-Sipmann F, Bohm SH, Pech T, Reissmann H, Meschino G. Monitoring dead space during recruitment and PEEP

Mr Kallet has disclosed a relationship with Phillips/Respironics. The other authors have disclosed no conflicts of interest.

Correspondence: Richard H Kallet MSc RRT FAARC, Respiratory Care Services, San Francisco General Hospital, NH:GA-2, 1001 Potrero Avenue, San Francisco CA 94110. E-mail: rich.kallet@ucsf.edu.

DOI: $10.4187 /$ respcare. 01737 titration in experimental model. Intensive Care Med 2006;32(11): 1863-1871.

22. Tusman G, Suarez-Sipmann F, Bohm SH, Borges JB, Hendenstierna G. Capnography reflects ventilation/perfusion distribution in a model of acute lung injury. Acta Anaesthesiol Scand 2011;55(5):597-606.

23. Robertson HT, Swenson ER. What do dead-space measurements tell us about the lung with acute respiratory distress syndrome? Respir Care 2004;49(9):1006-1007.

24. Feihl F, Melot C, Brimioulle S. Pulmonary dead space and survival. N Engl J Med 2002;347(1):347.

25. Murray JF, Matthay MA, Luce JM, Flick MR. An expanded definition of the adult respiratory distress syndrome. Am Rev Respir Dis 1988;138(4):720-723.

26. Doyle RL, Szaflarski N, Modin GW, Wiener-Kronish JP, Matthay MA. Identification of patients with acute lung injury: predictors of mortality. Am J Respir Crit Care Med 1995;152(6):1818-1824.

27. Kallet RH, Daniel B, Garcia O, Matthay MA. Accuracy of physiologic dead space measurements in patients with acute respiratory distress syndrome using volumetric capnography: Comparison with the metabolic monitor method. Respir Care 2005;50(4): 462-467. 